\title{
A PRELIMINERY STUDY ON LENGTH-WEIGHT RELATIONSHIP OF THE MUDSKIPPER Boleophthalmus boddarti IN SOC TRANG
}

\author{
Dinh Minh Quang
}

Can Tho University, *dmquang@ctu.edu.vn

\begin{abstract}
Boleophthalmus boddarti (Pallas, 1770) is one of mudskippers (Gobiidae), and a potential commercial fish in Mekong Delta, Vietnam. The study on the goby B. boddarti was investigated in Tran De district, Soc Trang province, Mekong Delta, Vietnam, to establish some basic population biology parameters. A total of 117 individuals were caught in mudflats of Tran De beach by deep net to determine length-weight relationships of this species. After determining sex by external features, total length ( $T L$ in $\mathrm{cm}$ ), and body weight ( $W$ in $\mathrm{g}$ ) of this goby were measured. This study ran for six months, from January 2013 to June 2013. The mean lengths of female significantly differed from value of male, whereas the average body weights of male and female were quite similar. The proportion of male and female groups were not substantially different. The length-weight relationships of total fish, male and female were highly correlated with high regression values which were $0.813,0.866$ and 0.767 , respectively. The slope values of this mudskipper was $3.21 \pm 0.32$ which was not significant higher cubic value (three), suggesting the growth relationship of this species was isometric growth and could be a potential fish for future aquaculture.
\end{abstract}

Keywords: Boleophthalmus boddarti, isometric growth, length-weight relationship, slope value, Soc Trang.

\section{INTRODUCTION}

The blue-spotted

mudskipper Boleophthalmus boddarti (fig. 1) is common one of an amphibious fishes inhabiting in the muddy area of coastlines and estuaries in Soc Trang province, Mekong Delta, Vietnam [7]. This species can use the air surrounding surface of the mudflat for breathing and use burrows as place of living, forging prey and refuge from predators $[2,15]$. This species is one potential commercial fish in Mekong Delta [15]. However, there has been little know on this species like its distribution, external morphology, environmental adaptation [7], geographic distribution [4], burrowing morphology and utilization [2, 15], and diet reference [16]. Meanwhile, relationship between weight and length (WLR), which can serve as an indicator for stock assessment and fishery management $[3,8,12,14]$, of this mudskipper $B$. boddarti has not known, especially in Mekong Delta where dry and wet seasons are distinctive and fish habitats are severely affected by heavy flooding as a consequence of climate change [11].

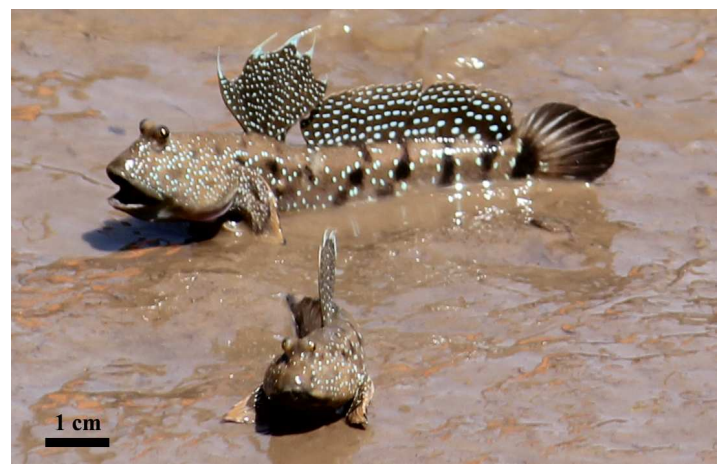

Fig. 1. Boleophthalmus boddarti

It can be postulated that (1) $T L$ and $W$ means and proportion of male and female will be similar, and (2) WLRs of the blue-spotted mudskipper will have a strong relationship and the slope values $(b)$ will share the same pattern in two genders and show isometric growth. The result of this study may contribute not only to fill in scientific knowledge gaps on WLR and slope value of this mudskipper, but also to stock assessment on this mudskipper.

\section{MATERIALS AND METHODS}


The blue-spotted fish was monthly collected by deep net at mudflats of Tran De beach $\left(9^{\circ} 28^{\prime} 47.41^{\prime \prime} \mathrm{N}, 106^{\circ} 12^{\prime} 25.96 " \mathrm{E}\right)$ (fig. 2) from January to June 2013. The mudflat of this place comprised mainly mud and sand. Specimens was immediately stored in a plastic can with formalin fluid (10\% in volume) in the field before bringing back to Animal Laboratory, Department of Biology, School of Education, Can Tho University. In the laboratory, the mudskippers were measured divided in genders by external morphology, thereafter, the total length and standard length in $0.1 \mathrm{~cm}$, and it was also weighted in digital scale in $0.01 \mathrm{~g}$.

WRLs of male and female of mudskippers were calculated based on equation $W=a \times T L^{b}$ of Ricker (1973) [17], where $W$ is body weight of the fish $(\mathrm{g}), T L$ is total length (cm) and $a$ (intercept) and $b$ (slope value) are two model parameters. The values of $a$ and $b$ were estimated by using logarithmic form of the variables $\log W=\log a+b \times \log T L$, where $a$ and $b$ of Ricker equation are $(\log a)^{10}$, and $b$ of logarithmic equation, respectively [5]. This method was used by Vicentin et al. (2012) [18] and Lawson (2011) [10] to determined length weight relationship of fish species in the upper Miranda River (Southern Pantanal wetland, Brazil) and Periophthalmus papilio in the mangrove swamps of Lagos Lagoon (Nigeria), respectively, and many scientists around the world to carry out the relationship between length and weight of numerous fishes.

Minitab package software version 16.0 was used to test the differences in percentage of genders and $T L$ and $W$ of male and female of this species during period of study.

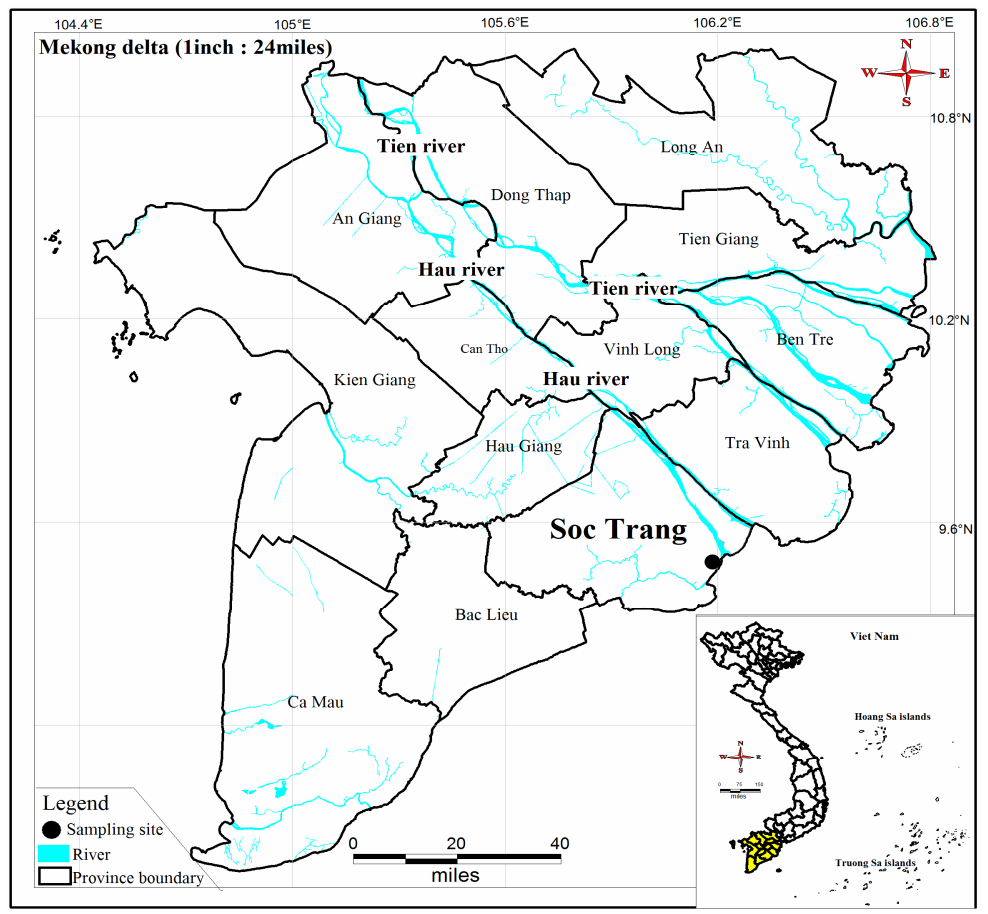

Fig. 2. Sampling site

\section{RESULTS AND DISCUSSION}

\section{Morphometric data}

The mean of total lengths for total fish, male and female individuals were 13.38 \pm 1.16 , $13.13 \pm 1.20$ and $13.67 \pm 1.06 \mathrm{~cm}$ respectively. The average body weights for total fishes, males and females were 22.48 $\pm 7.00,21.34 \pm 5.92$, 
23.81 \pm 7.94 , respectively. The $T L$ and $W$ means of female ranked first which followed by numbers of male and total fish.

The means of total length of females were significantly higher than that of males at confidence level 95\% (ANOVA, $\mathrm{df}=1, \mathrm{~F}=6.42$, $P<0.05)$. However, the mean body weights of males and females were not significantly different at meaningful level $\alpha=0.05$ (ANOVA, $\mathrm{df}=1, \mathrm{~F}=3.69, P>0.05)$, suggesting that males and females fishes were quite similar in growth type.

The proportion of males was slightly lower than that of females, which were 0.43 and 0.57 for male and female, respectively. However, the difference between these genders was not significantly at meaningful level $\alpha=0.05$ based on $\chi^{2}$ test (Chi-square Goodness-of-Fit test, $\left.\chi^{2}=0.692, P>0.05\right)$.

\section{Weight-length relationship}

WRLs of total fish, male and female were highly correlated based on high regression coefficients $\left(R^{2}\right)$ which were $0.813,0.866$ and 0.767 for total fish, male and female, respectively. Slope values $(b)$ of total fish, male and female were 3.13, 2.94 and 3.57, respectively. The slope value of male was slightly higher than that of total fish and female, whereas the regression coefficient of females ranked first followed by that numbers of total fish and males. June was spawning time of many kinds of fishes in Mekong Delta and estuaries including this species which lead to body weight of female fishes was slightly heavier than that of males. It may cause in the higher slope value in females than males.

The regression between $W$ and $T L$ of total fish, female and male were presented in following linear equations and in fig. 3 .

$$
W=0.006 \times T L^{3.13}
$$

(Total fish, $\mathrm{n}=117, R^{2}=0.974$ )

$$
W=0.010 \times T L^{2.94}
$$

(Male, $\mathrm{n}=54, R^{2}=0.954$ )

$$
W=0.002 \times T L^{3.57}
$$

(Female, $\mathrm{n}=63, R^{2}=0.931$ )
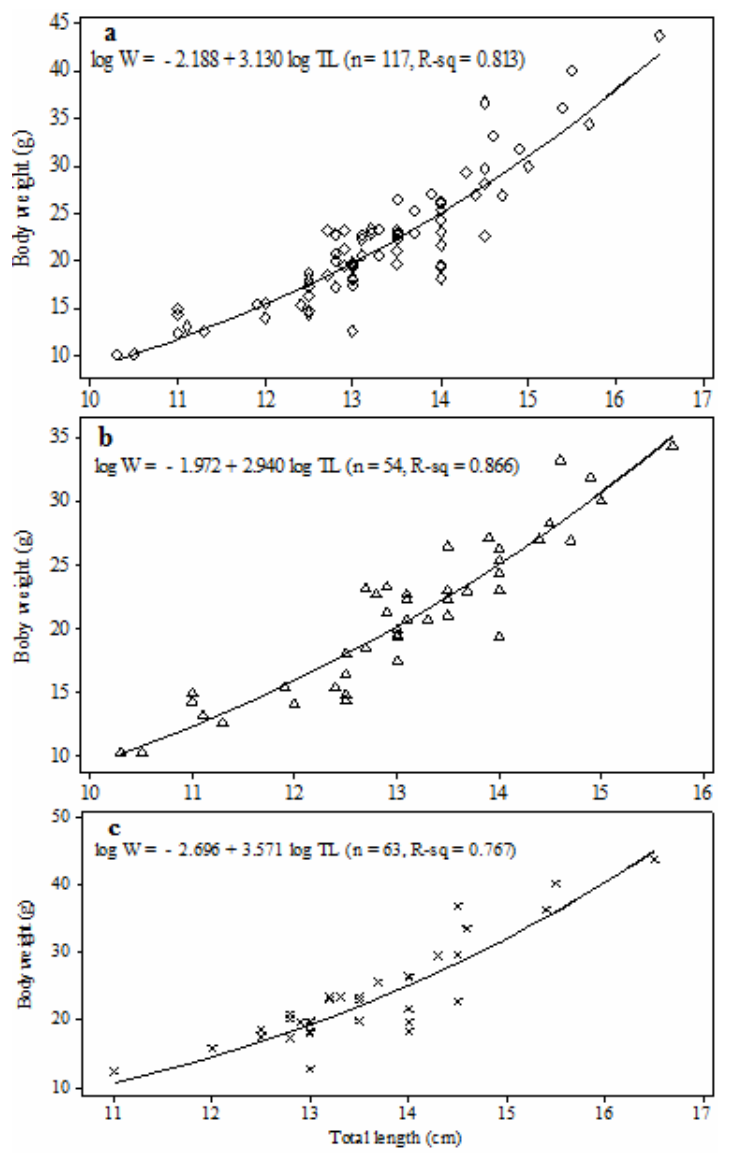

Fig. 3. WRLs of total fish (a), female (b), male (c)

Mean of the slope of this mudskipper was $3.21 \pm 0.32$ which was not significantly higher 3 at confidence level $95 \%$ based on $t$ test (1sample $\mathrm{t}$ test, $\mathrm{t}=1.14, P>0.05)$, indicating that this fish showed isometric growth. This mean that this mudskipper could increase in three dimensions of this body (high, width and length) like a cubic shape by time based on scale of Froese \& Binohlan (2000) [6], suggesting that this fish could be become a potential fish for future artificial aquaculture. This was quite similar to study on fish species collected from Manora Channel and associated backwaters (the northern Arabian Sea) of Khatoon et al. (2013) [9], some fish species of the Iberian Peninsula of Oscoz et al. (2005) [13], and fish species discarded in commercial fisheries of the Algarve of Borges et al. (2003) 
[1]. However, this study did not tested the some factors like stomach, gonad maturity, sex and age affecting the slope values of $b$, which was similar to study of Khatoon et al. (2013) [9]; Wigley et al. (2003) [19].

\section{CONCLUSION}

This study indicated that mean of fish weight was not significantly different between two genders and proportion of male and female was quite similar, which coincided with prediction. However, mean of fish size was significantly different which was not coincided with prediction.

WRLs of this mudskipper was high correlated and shared the nearly the same pattern in male, female and total fish groups. The slope value of this species was not significantly higher than three, suggesting this fish showed isometric growth and could become future potential artificial aquaculture. These results were coincident with projection.

Acknowledgment: I am grateful to Mr. Giang (local fishermen) and Mr. Tuan (my friend) and Mr. Thanh (my colleague) for catching fish, my students (Mr. Huy, Ms. Trang, Ms. Nhu and Ms. Giang) for measuring fish length and weight.

\section{REFERENCES}

1. Borges T., Olim S., Erzini K., 2003. Weight-length relationships for fish species discarded in commercial fisheries of the Algarve (southern Portugal). J. Appl. Ichthyol., 19(6): 394-396.

2. Clayton D., Vaughan T., 1986. Territorial acquisition in the mudskipper Boleophthalmus boddarti (Teleostei, Gobiidae) on the mudflats of Kuwait. J. Zool., 209(4): 501-519.

3. Deval M. C., Bok T., Ates C., Tosunoglu Z., 2007. Length-based estimates of growth parameters, mortality rates, and recruitment of Astacus leptodactylus (Eschscholtz, 1823) (Decapoda, Astacidae) in unexploited inland waters of the northern Marmara region, European Turkey). Crustaceana,
80(6): 655-665, doi: 10.1163/1568540077 81360649

4. Dinh T. D., Koichi S., Phuong N. T., Hung H. P., Loi T. X., Hieu M. V., Kenzo U., 2013. Fishes of Mekong Delta, Vietnam. Can Tho: Can Tho University publisher, 174 pages.

5. Froese R., 2006. Cube law, condition factor and weight-length relationships: history, meta-analysis and recommendations. J. Appl. Ichthyol., 22(4): 241-253.

6. Froese R., Binohlan C., 2000. Empirical relationships to estimate asymptotic length, length at first maturity and length at maximum yield per recruit in fishes, with a simple method to evaluate length frequency data. J. Fish Biol., 56(4): 758-773, doi: 10.1111/j.1095-8649.2000.tb00870.x

7. Froese R., Pauly D., 2014. Version (02/2014). FishBase. Retrieved 27/02, 2014, from www.fishbase.org.

8. Gonzalez A. A., De La Cruz Agüero G., De La Cruz Agüero J., 2004. Length-weight relationships of fish species caught in a mangrove swamp in the Gulf of California (Mexico). J. Appl. Ichthyol., 20(2): 154155.

9. Khatoon Z., Paperno R., Hussain S., 2013. Length-weight relationships of five fish species collected from Manora Channel and associated backwaters of the northern Arabian Sea. J. Appl. Ichthyol., 30(1): 235238.

10. Lawson E., 2011. Length-weight relationships and fecundity estimates in mudskipper, Periophthalmus papilio (Bloch and Schneider 1801) caught from the mangrove swamps of Lagos Lagoon, Nigeria. J. Fish. Aquat. Sci., 6: 264-271.

11. Le T. V. H., Nguyen H. N., Wolanski E., Tran T. C., Haruyama S., 2007. The combined impact on the flooding in Vietnam's Mekong River delta of local manmade structures, sea level rise, and dams upstream in the river catchment. Estuar Coast Shelf S., 71(1-2): 110-116, doi: 10.1016/j.ecss.2006.08.021. 
12. Mahmood K., Ayub Z., Moazzam M., Siddiqui G., 2012. Length-Weight Relationship and Condition Factor of Ilisha melastoma (Clupeiformes: Pristigasteridae) Off Pakistan. Pakistan J. Zool., 44(1): 71-77.

13. Oscoz J., Campos F., Escala M., 2005. Weight-length relationships of some fish species of the Iberian Peninsula. J. Appl. Ichthyol., 21(1): 73-74.

14. Pauly D., Morgan G., 1987. Length-based methods in fisheries research. Paper presented at the Proceeding of the International Conference on the Theory and Application of Length-Based Methods for Stock Assessment, Mazzara del Vallo, Sicily, Italy.

15. Quang D. M., 2013. Burrow and the role of burrow toward to mudskipper, Beleophthalmus boddarti (Pallas, 1770). Paper presented at the National conference of Young Researchers 2013, Da Nang University of Education, 162-166.
16. Ravi V., 2013. Food and Feeding Habits of the Mudskipper, Boleophthalmus boddarti (Pallas, 1770) from Pichavaram Mangroves, Southeast Coast of India. Inter. J., 3(12): 98104.

17. Ricker W. E., 1973. Linear Regressions in Fishery Research. Journal of the Fisheries Research Board of Canada, 30(3): 409-434, doi: 10.1139/f73-072.

18. Vicentin W., dos S. Costa F. E., Súarez Y. R., 2012. Length-weight relationships and length at first maturity for fish species in the upper Miranda River, southern Pantanal wetland, Brazil. J. Appl. Ichthyol., 28(1): 143-145, doi: 10.1111/j.14390426.2011.01890.x.

19. Wigley S., McBride H., McHugh N., 2003. Length-weight relationships for 74 fish species collected during NEFSC research vessel bottom trawl surveys. NOAA Technical Memorandum NMFS-NE, 171.

\title{
NGHIÊN CÚUU BƯỚC ĐẦU VỀ TƯƠNG QUAN CHIỀU DÀI - KHỐI LƯỢNG CÁ BỐNG SAO Boleophthalmus boddarti Ở SÓC TRĂNG
}

\author{
Đinh Minh Quang
}

Trường Đại học Cần Thơ

\section{TÓM TÁT}

Boleophthalmus boddarti (Pallas, 1770) là một trong những loài cá bùn (Gobiidae), và cũng là một loài cá có niềm năng kinh tế ở vùng Đồng bằng sông Cửu Long, Việt Nam. Bài báo giới thiệu kết quả nghiên cứu về mối quan hệ giữa chiều dài tổng và khối lượng cơ thể của loài cá bùn này. Trung bình chiều dài tổng của cá cái lớn hơn cá đực có nghĩa về mặt thống kê, trong khi đó trung bình khối lượng cơ thể và tỷ lệ giới tính của nhóm cá đực và cái như nhau. Chiều dài cơ thể ở ba nhóm cá nghiên cứu có mối quan hệ chặt chẽ với khối lượng tương ứng của chúng được chứng minh qua hệ số tương quan của những đường hồi quy tuyến tính. Các số liệu này lần lượt tương ứng với ba nhóm cá nghiên cứu là $0,813,0,866$ và 0,767 . Hằng số slope của loài này là $3,21 \pm 0,32$ và không lớn hơn nhiều so với hệ số chuẩn là ba, điều này cho thấy loài này sẽ đều ở cả 3 hướng (cao, rộng và dài) theo thời gian và có thể sử dụng như chỉ số để theo dõi trong nuôi trồng thủy sản.

Tù khóa: Boleophthalmus boddarti, phát triển đồng bộ, tương quan chiều dài-khối lượng, Sóc Trăng. 